\title{
Investigation of T Factor Variations along Atrak River to the Caspian Sea
}

\author{
Elaheh Javadi Mousavi1, Mehran Arian ${ }^{1 *}$, Manochehr Ghorashi ${ }^{2}$ \\ ${ }^{1}$ Department of Geology, Science and Research Branch, Islamic Azad University, Tehran, Iran \\ ${ }^{2}$ Department of Geology, North Tehran Branch, Islamic Azad University, Tehran, Iran \\ Email: *mehranarian@yahoo.com
}

How to cite this paper: Mousavi, E.J., Arian, M. and Ghorashi, M. (2017) Investigation of T Factor Variations along Atrak River to the Caspian Sea. Open Journal of Marine Science, 7, 35-50.

http://dx.doi.org/10.4236/ojms.2017.71004

Received: August 28, 2016

Accepted: December 3, 2016

Published: December 6, 2016

Copyright (@) 2017 by authors and Scientific Research Publishing Inc. This work is licensed under the Creative Commons Attribution International License (CC BY 4.0).

http://creativecommons.org/licenses/by/4.0/ cc) (i)

\section{Open Access}

\begin{abstract}
The study area has located on Atrak river basin in the Iran-Turkmenistan border zone that is the greatest river on the southeastern margin of Caspian Sea. The study area was divided into 56 sub-basins and then $\mathrm{T}$ factors were calculated for all streams of the Atrak river. $\mathrm{T}$ factor is a geomorphic index for tilting identification by active tectonics. Our results show that, there are low, moderate and high relative tectonic activities levels. Low relative tectonic activities level has been found in sub-basins No. $1,2,3,4,10,23,25,41$ and 51, moderate relative tectonic activities level has been found in sub-basins No. 5, 6, 7, 8, 13, 14, 17, 18, 19, 20, 21, 24, 28, 29, 30, 31, 32, 34, $35,39,40,42,43,46,47,48,49,50,52,53,55$ and 56 and high relative tectonic activities level has been found in sub-basins No. 9, 11, 12, 15, 16, 22, 26, 27, 33, 36, 37, 38, 44, 45 and 54. Also, most part of the study area has got moderate tectonic activity that it is compatible with its tectonic setting on the Kopetdagh belt in Iran. It is shows that some sub-basins on the western parts of study area that river has got westeast trending, are more active. But, some sub-basins on the eastern parts of study area that river has got northwest-southeast trending, are less active. It means that migration direction of the most streams are toward north and south and the major faults and folds in the western parts of study area caused river tilting be perpendicular to structural trend. This variation along the most important river on the northeastern part of Iran was analyzed for the first time in this research.
\end{abstract}

\section{Keywords}

T Factor, River, Atrak, Tectonic, Caspian Sea

\section{Introduction}

Atrak is a bed rock river which begins in the mountains of north-eastern Iran, and flows 669 kilometers westward draining into the Caspian Sea in Turkmenistan. The Atrak River is located in the north east Iran (Figure 1). The Atrak river is located in the 


\section{Physiographic-tectonic zoning map of Iran's sedimentary basins}

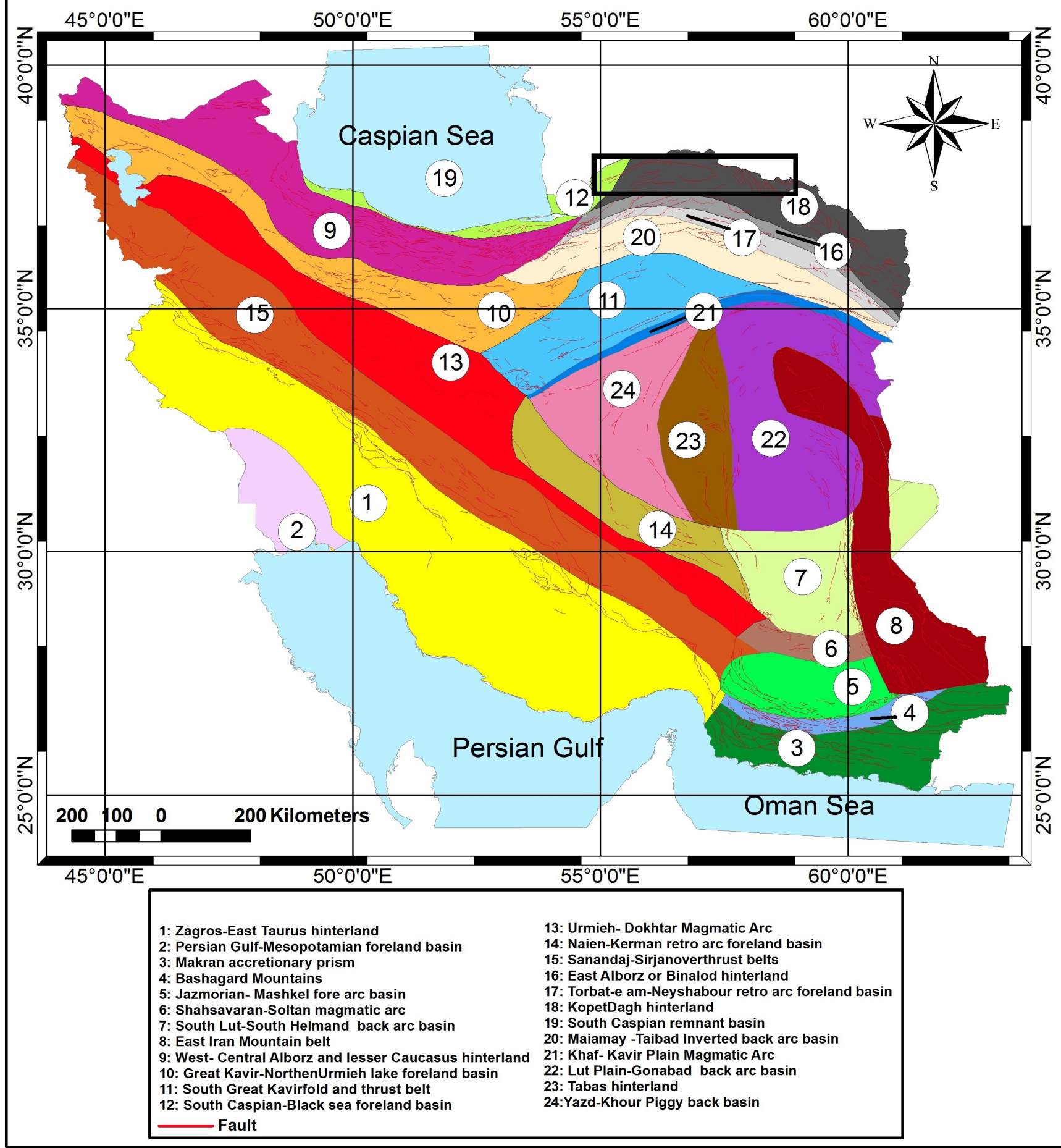

Figure 1. Physiographic-tectonic zoning map of Iran's sedimentary basins, modified from [1]. The study area is shown in the black rectangle.

Kopetdagh and it is divided into 56 sub-basins (Figure 2). This area belongs to Kopetdagh geologic province [1] [2]. Dominant structural trend in Kopetdagh province (Figure 3) is NW-SE. From tectonics view, it contains the Kopetdagh hinterland or 


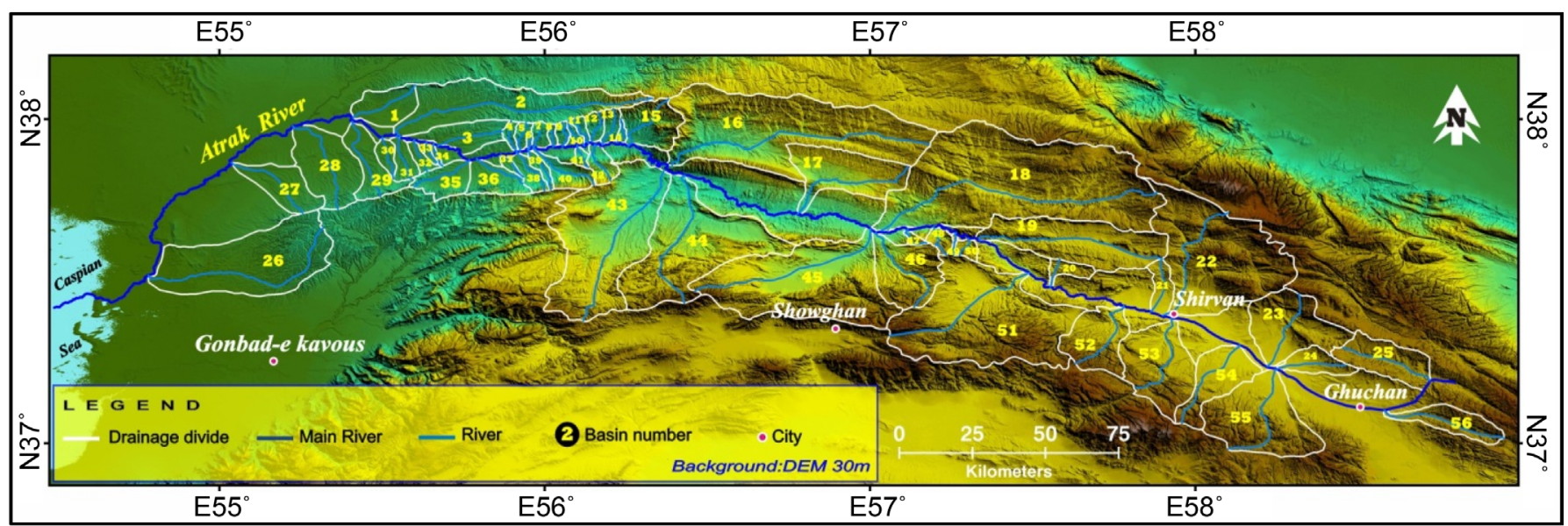

Figure 2. The fifty six sub-basins of the Atrak River basin, modified from [72].
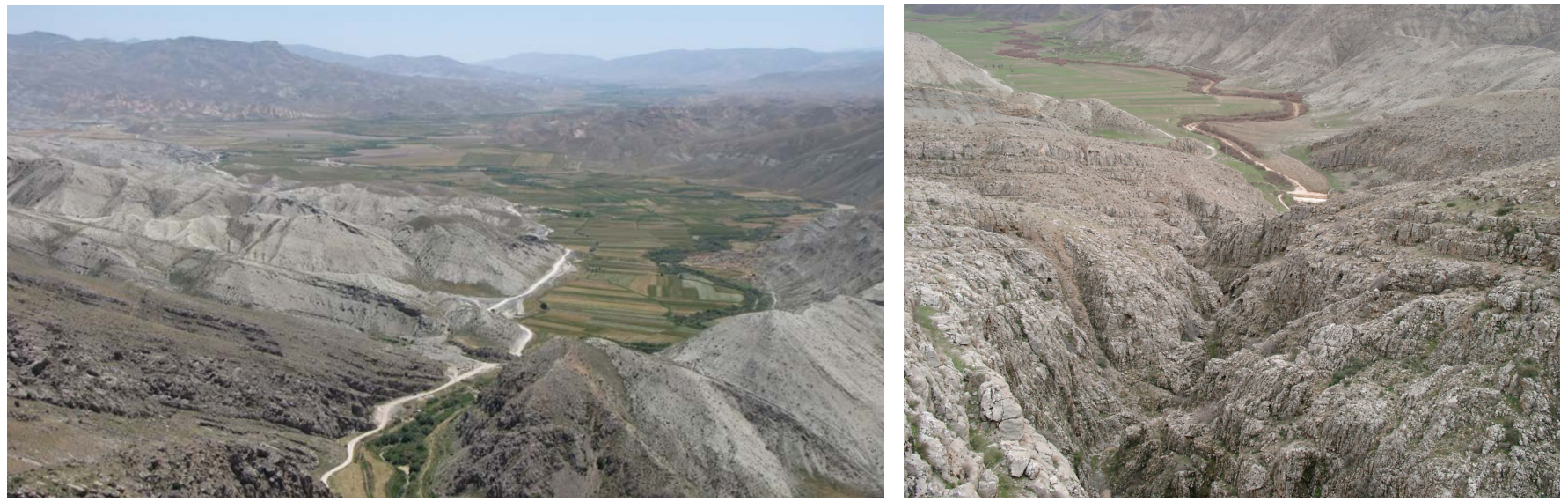

Figure 3. Two views from the Atrak streams (toward west) that show transverse topographic asymmetry in sub-basins No. 22 (left) and No. 17 (right).

Kopetdagh fold and thrust belt that formed in passive margin of Eurasian plate until late Triassic and then marine sedimentation on Kopetdagh proforeland basin has continued to Eocene. Kopetdagh hinterland has uplifted related to Karakorum foreland basin in northeast along Eshghabad fault.

The western part of studied area has located in South Caspian foreland basin. Dominant structural trend in South Caspian foreland basin province (Figure 3) is NW-SE. From tectonics view, it contains the northern foreland basin of West-Central Alborz and lesser Caucasus hinterland in the south margin of Eurasian plate since late Eocene. Although, median part of South Caspian and Black sea basin has uplifted by collision between Eurasian and Cimmerian plates [3].

Based on previous work on the salt and mud diapirism [4]-[15] and neotectonic regime in Iran [16]-[21], Zagros in south Iran is the most active zone [22]-[43]. Then, Alborz [44]-[83] and Central Iran [84]-[99] have been situated in the next orders.

\section{Materials and Methods}

The calculation of transverse topographic symmetry factor $(\mathrm{T})$ is suitable for rapid assessment of active tectonics. Therefore, transverse topographic symmetry factors have 
calculated for the streams in the Atrak River. Based on digital elevation model of Atrak River, there are 56 sub-basins. The study area is located between longitudes $55^{\circ} \mathrm{E}-59^{\circ} \mathrm{E}$ and latitudes $37^{\circ} \mathrm{N}-38^{\circ} \mathrm{N}$ in the Northern Khorasan province, in the north east part of Iran.

The study area is mainly composed of limestone (Tiregan Formation), marl (Sarcheshmeh Formation), shale and marl (Sanganeh Formation), sandstone and shale (Aitamir Formation) and Quaternary alluvial deposits The East Alborz or Binalod Mountains are parallel to the Kopetdagh hinterland on the north east Iran. The Atrak valley, which separates the East Alborz and Kopetdagh, forms a major structural boundary between Central Iran and Eurasia, known as the Paleo-Tethyian suture zone, which formed before the Alpine-Himalayan orogenies since late Triassic.

\section{Transverse Topographic Symmetry Factor (T)}

The transverse topographic symmetry factor $(\mathrm{T})$ was calculated as follows:

$$
\mathrm{T}=D a / D d
$$

which $D a$ is the space from the midline of the drainage basin to the midline of the active belt and $D d$ is the space from the midline to the basin limit [100]. In a completely symmetric basin $\mathrm{T}=0$ and as asymmetry increases $\mathrm{T}$ approaches to value of 1.0 [101]. Two views from the Atrak streams that used for calculation of $\mathrm{T}$ index in study area have presented in Figure 3.

Finally, we can consider class 1 for $\mathrm{T}>0.4$, class 2 for $\mathrm{T}$ between 0.2 and 0.4 and class 3 for $\mathrm{T}<0.2$ and so, sub-basins No. $9,11,12,15,16,22,26,27,33,36,37,38,44,45$ and 54 shows higher activity (Table 1 and Figure 4 ).

\section{Results and Discussion}

There are three level of active tectonics. Low relative tectonic activities in sub-basins No. 1, 2, 3, 4, 10, 23, 25, 41 and 51, moderate relative tectonic activities in sub-basins No. 5, 6, 7, 8, 13, 14, 17, 18, 19, 20, 21, 24, 28, 29, 30, 31, 32, 34, 35, 39, 40, 42, 43, 46, 47, $48,49,50,52,53,55$ and 56 and finally high relative tectonic activities in sub-basin No. $9,11,12,15,16,22,26,27,33,36,37,38,44,45$ and 54 (Figure 4). On the other hand,

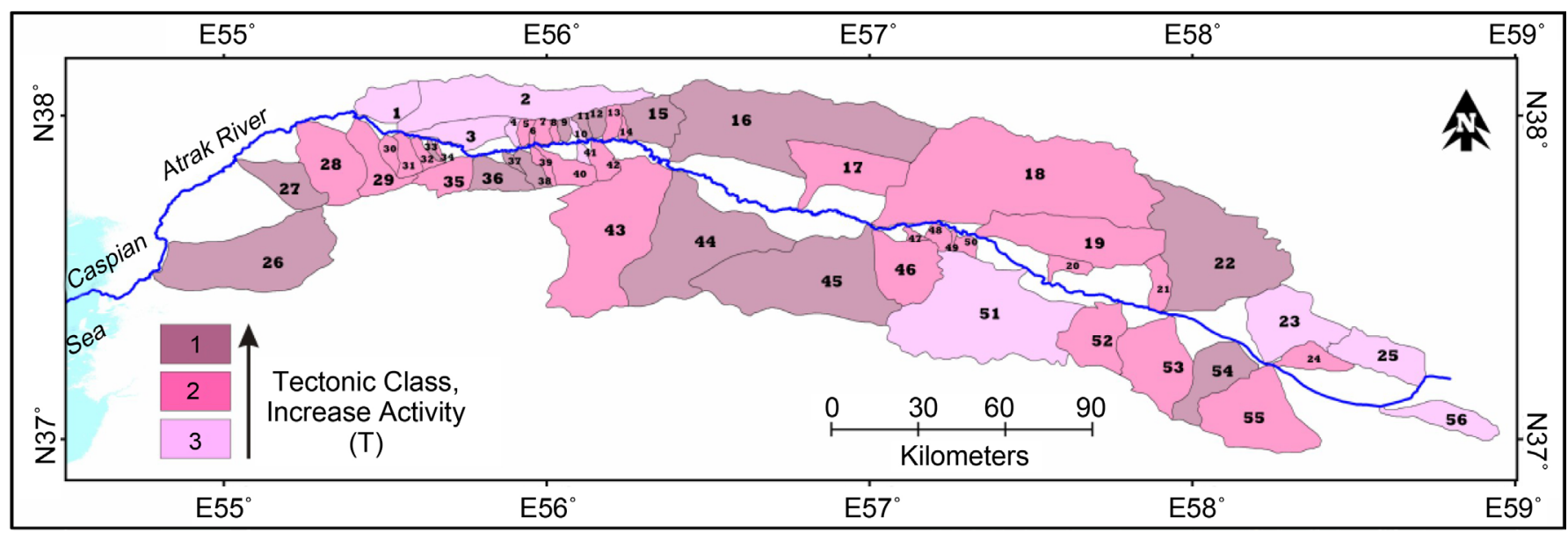

Figure 4. The classification map for $\mathrm{T}$ index. 
Table 1. Values of $\mathrm{T}$ index for sub-basins.

\begin{tabular}{|c|c|c|c|c|c|c|}
\hline \multicolumn{7}{|c|}{ Transverse topographic symmetry Factor $(\mathrm{T})$} \\
\hline Basin & Number & $D a(\mathrm{~m})$ & $D d(\mathrm{~m})$ & $T(\mathrm{~m})$ & $T_{\text {ave }}(\mathrm{m})$ & Tectonic class \\
\hline \multirow{4}{*}{1} & 1 & 260.9 & 1937 & 0.13 & \multirow{4}{*}{0.18} & \multirow{4}{*}{3 (Low Activity) } \\
\hline & 2 & 1197 & 5180 & 0.23 & & \\
\hline & 3 & 353.7 & 5310 & 0.07 & & \\
\hline & 4 & 485.1 & 1593 & 0.30 & & \\
\hline \multirow{4}{*}{2} & 1 & 56.2 & 1531 & 0.04 & \multirow{4}{*}{0.16} & \multirow{4}{*}{3} \\
\hline & 2 & 478.8 & 5820 & 0.08 & & \\
\hline & 3 & 1840 & 7490 & 0.25 & & \\
\hline & 4 & 1110 & 4204 & 0.26 & & \\
\hline \multirow[b]{2}{*}{3} & 1 & 398.6 & 5750 & 0.07 & \multirow[b]{2}{*}{0.11} & \multirow[b]{2}{*}{3} \\
\hline & 2 & 391.5 & 2771 & 0.14 & & \\
\hline \multirow{3}{*}{4} & 1 & 183.6 & 1993 & 0.09 & \multirow{3}{*}{0.13} & \multirow{3}{*}{3} \\
\hline & 2 & 228.5 & 1151 & 0.20 & & \\
\hline & 3 & 86.8 & 933.9 & 0.09 & & \\
\hline \multirow{4}{*}{5} & 1 & 442.2 & 2316 & 0.19 & \multirow{4}{*}{0.25} & \multirow{4}{*}{2 (Moderate Activity) } \\
\hline & 2 & 456.6 & 1776 & 0.26 & & \\
\hline & 3 & 707.1 & 1532 & 0.46 & & \\
\hline & 4 & 113.4 & 1475 & 0.08 & & \\
\hline \multirow[b]{2}{*}{6} & 1 & 56 & 509.9 & 0.11 & \multirow[b]{2}{*}{0.21} & \multirow[b]{2}{*}{2} \\
\hline & 2 & 241.1 & 766.3 & & & \\
\hline 7 & 1 & 503.6 & 2114 & 0.24 & 0.24 & 2 \\
\hline \multirow[b]{2}{*}{8} & 1 & 250.1 & 1015 & 0.25 & \multirow{2}{*}{0.25} & \multirow[b]{2}{*}{2} \\
\hline & 2 & 313 & 1217 & 0.26 & & \\
\hline \multirow{2}{*}{9} & 1 & 813 & 1574 & 0.52 & \multirow{2}{*}{0.57} & \multirow{2}{*}{1 (High Activity) } \\
\hline & 2 & 1256 & 2007 & 0.63 & & \\
\hline \multirow[b]{2}{*}{10} & 1 & 367 & 1445 & 0.25 & & \\
\hline & 2 & 184.6 & 1454 & 0.13 & 0.19 & 3 \\
\hline & 1 & 577 & 2281 & 0.25 & & \\
\hline 11 & 2 & 1214 & 1497 & 0.81 & 0.54 & 1 \\
\hline & 3 & 568 & 997.3 & 0.57 & & \\
\hline & 1 & 1528 & 2322 & 0.66 & & \\
\hline 12 & & & & & 0.70 & 1 \\
\hline & 2 & 883 & 1196 & 0.74 & & \\
\hline & 1 & 746 & 2475 & 0.30 & & \\
\hline 13 & 2 & 478.2 & 2389 & 0.20 & 0.26 & 2 \\
\hline & 3 & 351 & 1296 & 0.27 & & \\
\hline & 1 & 176 & 583.5 & 0.30 & & \\
\hline 14 & 2 & 383 & 1129 & 0.34 & 0.35 & 2 \\
\hline & 3 & 640 & 1589 & 0.40 & & \\
\hline
\end{tabular}




\section{Continued}

\begin{tabular}{|c|c|c|c|c|c|c|}
\hline \multirow{3}{*}{15} & 1 & 397 & 851 & 0.47 & \multirow{3}{*}{0.44} & \multirow{3}{*}{1} \\
\hline & 2 & 474.1 & 10,630 & 0.04 & & \\
\hline & 3 & 2137 & 2595 & 0.82 & & \\
\hline \multirow{3}{*}{16} & 1 & 3935 & 7550 & 0.52 & \multirow{3}{*}{0.51} & \multirow{3}{*}{1} \\
\hline & 2 & 9420 & 15,040 & 0.63 & & \\
\hline & 3 & 862 & 2288 & 0.38 & & \\
\hline \multirow{4}{*}{17} & 1 & 2281 & 5020 & 0.45 & \multirow{4}{*}{0.37} & \multirow{4}{*}{2} \\
\hline & 2 & 4277 & 7020 & 0.61 & & \\
\hline & 3 & 513.4 & 2656 & 0.19 & & \\
\hline & 4 & 277 & 1244 & 0.22 & & \\
\hline \multirow{6}{*}{18} & 1 & 2438 & 7250 & 0.34 & \multirow{6}{*}{0.29} & \multirow{6}{*}{2} \\
\hline & 2 & 7800 & 12,850 & 0.61 & & \\
\hline & 3 & 4171 & 17,860 & 0.23 & & \\
\hline & 4 & 1970 & 21,080 & 0.09 & & \\
\hline & 5 & 499 & 9080 & 0.05 & & \\
\hline & 6 & 1120 & 2610 & 0.43 & & \\
\hline \multirow{5}{*}{19} & 1 & 2132 & 6010 & 0.35 & \multirow{5}{*}{0.27} & \multirow{5}{*}{2} \\
\hline & 2 & 740 & 8050 & 0.09 & & \\
\hline & 3 & 877 & 7790 & 0.11 & & \\
\hline & 4 & 3399 & 7380 & 0.46 & & \\
\hline & 5 & 2685 & 8100 & 0.33 & & \\
\hline \multirow{2}{*}{20} & 1 & 317 & 9870 & 0.03 & \multirow{2}{*}{0.24} & \multirow{2}{*}{2} \\
\hline & 2 & 395 & 884.7 & 0.45 & & \\
\hline \multirow{4}{*}{21} & 1 & 997 & 2671 & 0.37 & \multirow{4}{*}{0.27} & \multirow{4}{*}{2} \\
\hline & 2 & 157.2 & 2509 & 0.06 & & \\
\hline & 3 & 577 & 2884 & 0.20 & & \\
\hline & 4 & 1486 & 3390 & 0.44 & & \\
\hline \multirow{4}{*}{22} & 1 & 3874 & 18,590 & 0.21 & \multirow{4}{*}{0.43} & \multirow{4}{*}{1} \\
\hline & 2 & 6260 & 12,800 & 0.49 & & \\
\hline & 3 & 5290 & 7670 & 0.69 & & \\
\hline & 4 & 54.1 & 158.3 & 0.34 & & \\
\hline \multirow{3}{*}{23} & 1 & 1456 & 11,690 & 0.12 & \multirow{3}{*}{0.16} & \\
\hline & 2 & 998 & 8440 & 0.12 & & 3 \\
\hline & 3 & 501.1 & 2031 & 0.25 & & \\
\hline & 1 & 352.8 & 2631 & 0.13 & & \\
\hline & 2 & 782.2 & 6030 & 0.13 & & \\
\hline 24 & 3 & 786.2 & 5090 & 0.15 & 0.22 & 2 \\
\hline & 4 & 313.2 & 2786 & 0.11 & & \\
\hline & 5 & 150.7 & 272.3 & 0.55 & & \\
\hline
\end{tabular}




\section{Continued}

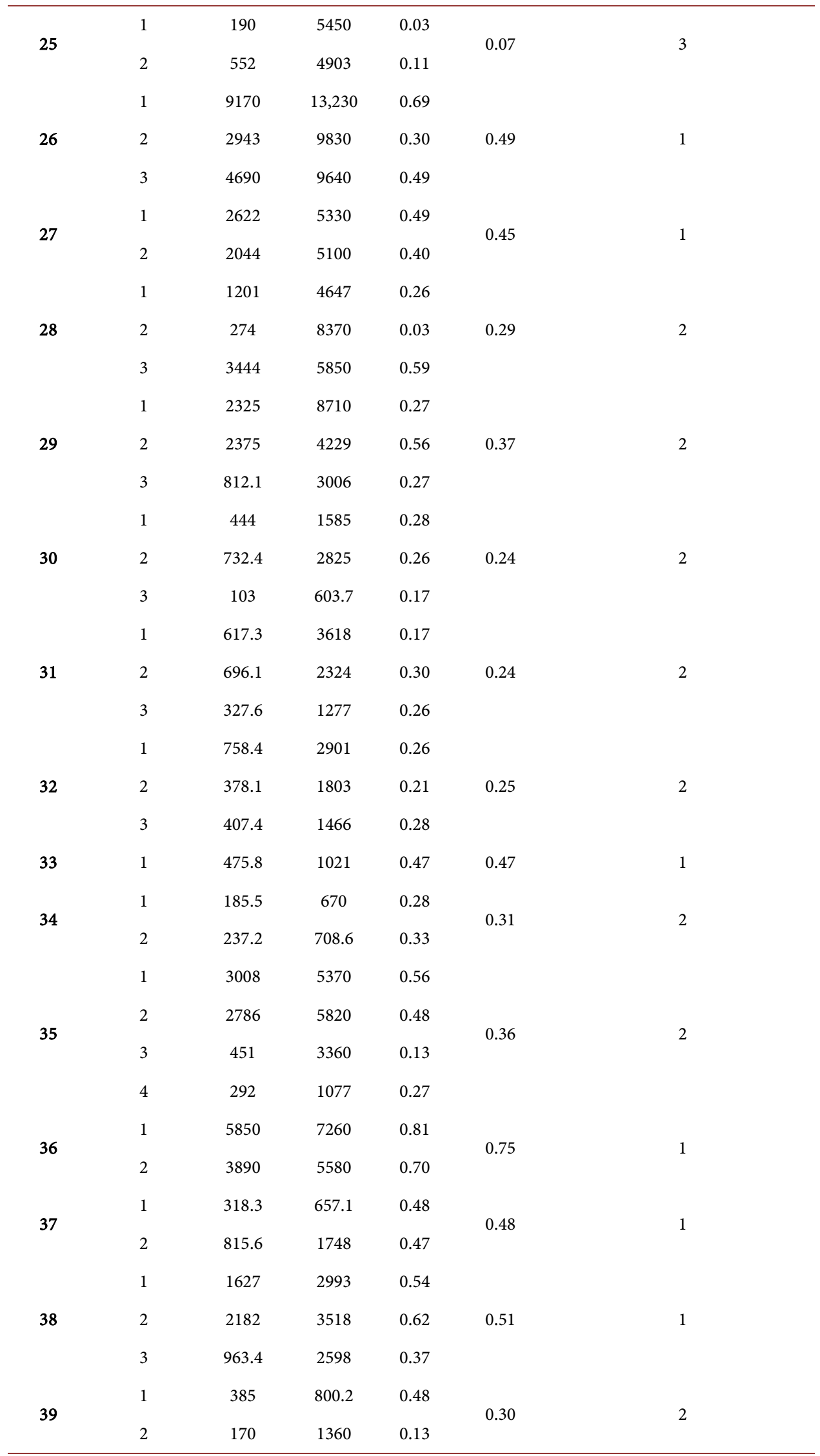




\section{Continued}

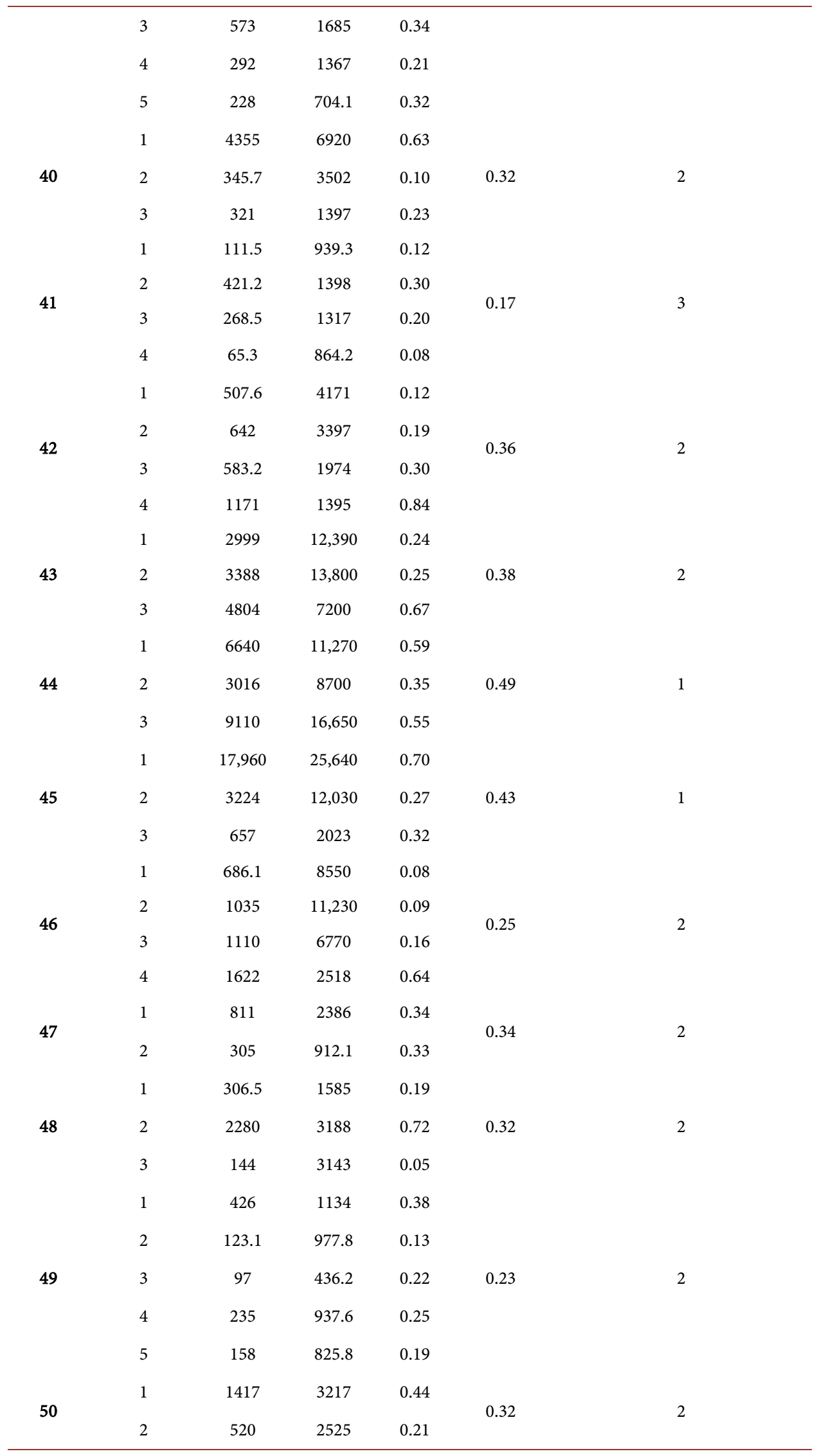




\section{Continued}

\begin{tabular}{|c|c|c|c|c|c|c|}
\hline \multirow{4}{*}{51} & 1 & 1538 & 8190 & 0.19 & \multirow{4}{*}{0.19} & \multirow{4}{*}{3} \\
\hline & 2 & 758 & 12,240 & 0.06 & & \\
\hline & 3 & 5930 & 23,290 & 0.25 & & \\
\hline & 4 & 782.7 & 3289 & 0.24 & & \\
\hline \multirow{3}{*}{52} & 1 & 1716 & 10,370 & 0.17 & \multirow{3}{*}{0.31} & \multirow{3}{*}{2} \\
\hline & 2 & 3021 & 6060 & 0.50 & & \\
\hline & 3 & 1622 & 6230 & 0.26 & & \\
\hline \multirow{3}{*}{53} & 1 & 2529 & 10,570 & 0.24 & \multirow{3}{*}{0.27} & \multirow{3}{*}{2} \\
\hline & 2 & 4294 & 10,160 & 0.42 & & \\
\hline & 3 & 675 & 4998 & 0.14 & & \\
\hline \multirow{3}{*}{54} & 1 & 2033 & 4416 & 0.46 & \multirow{3}{*}{0.48} & \multirow{3}{*}{1} \\
\hline & 2 & 2650 & 5370 & 0.49 & & \\
\hline & 3 & 3440 & 6920 & 0.50 & & \\
\hline \multirow[b]{2}{*}{55} & 1 & 4706 & 20,170 & 0.23 & \multirow[b]{2}{*}{0.26} & \multirow[b]{2}{*}{2} \\
\hline & 2 & 1583 & 5620 & 0.28 & & \\
\hline \multirow{5}{*}{56} & 1 & 625 & 3015 & 0.21 & \multirow{5}{*}{0.27} & \multirow{5}{*}{2} \\
\hline & 2 & 2029 & 3929 & 0.52 & & \\
\hline & 3 & 1166 & 4540 & 0.26 & & \\
\hline & 4 & 432 & 2025 & 0.21 & & \\
\hline & 5 & 130 & 806.2 & 0.16 & & \\
\hline
\end{tabular}

T classification: 1 (High Activity): >0.4, 2 (Moderate Activity): 0.2 - 0.4, 3 (Low Activity): <0.2.

although based on [102] northern side of sub-basin No. 46 or the Qharajeh area is inactive and its southern side is active, but $\mathrm{T}$ factor value is 0.25 .

Highest value of $\mathrm{T}$ index (0.81) for streams of Atrak river is related to sub-basins No. 11 and 36 and lowest value (0.03) is related to sub-basin No. 20 it seems that folds and thrusts parallel to this sub-basins caused more tilting. Calculating this geomorphic index for the study area shows that, average values of $\mathrm{T}$ factor are between 0.11 for subbasin No. 3 and 0.75 for sub-basin No. 36 which the latter case shows high seismicity (Figure 5).

It is shows that some sub-basins on the western parts of study area that river has got west-east trending, are more active. But, some sub-basins on the eastern parts of study area that river has got northwest-southeast trending, are less active. It means that migration direction of the most streams are toward north and south and the major faults and folds in the western parts of study area caused river tilting be perpendicular to structural trend.

Also, there are no logic relationship between the values of $\mathrm{T}$ index and seismic frequency. It has shown in Figure 5.

\section{Conclusions}

The $\mathrm{T}$ factor variations along the most important river on the southeastern margin of 


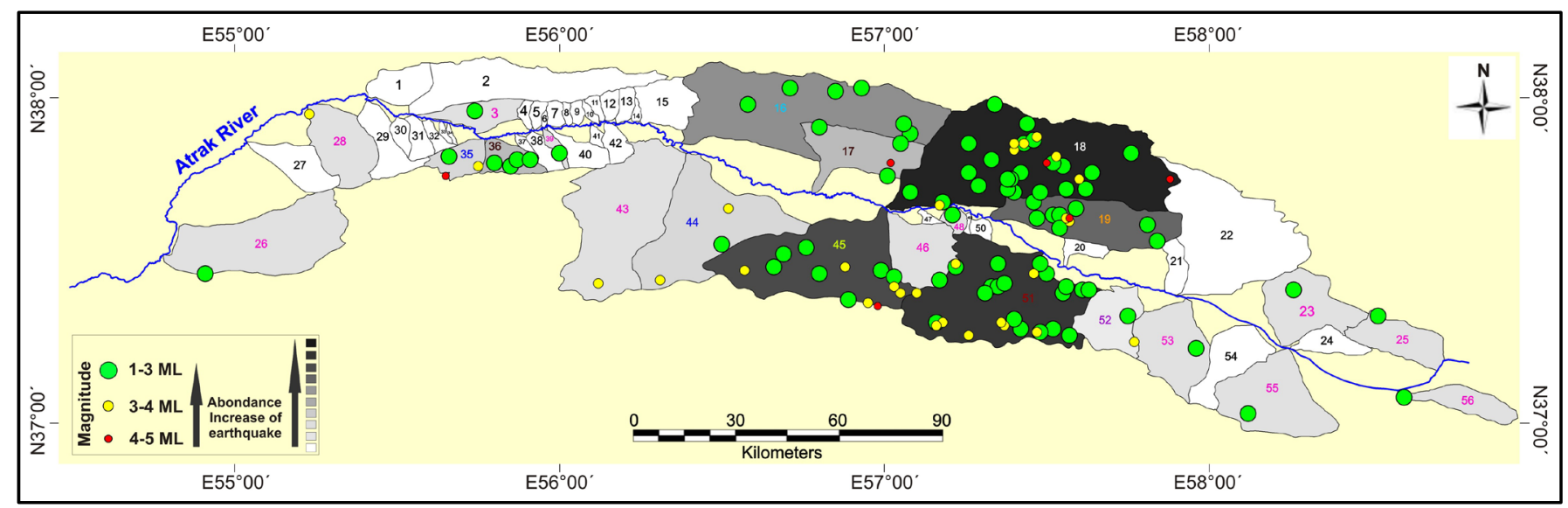

Figure 5. The seismic records of study area on sub-basin map (compare it with Figure 4).

Caspian Sea were analyzed for the first time in this research. The calculation of transverse topographic symmetry factor $(\mathrm{T})$ is suitable for rapid assessment of active tectonics. The transverse topographic symmetry factor has calculated in the Atrak River.

The study area was divided into 56 sub-basins and then transverse topographic symmetry factors were calculated for each one. Based on values of this index, there are low, moderate and high relative tectonic activities levels.

Low relative tectonic activities level has been found in sub-basins No. 1, 2, 3, 4, 10, 23, 25, 41 and 51, moderate relative tectonic activities level has been found in subbasins No. 5, 6, 7, 8, 13, 14, 17, 18, 19, 20, 21, 24, 28, 29, 30, 31, 32, 34, 35, 39, 40, 42, 43, $46,47,48,49,50,52,53,55$ and 56, and high relative tectonic activities level has been found in sub-basins No. $9,11,12,15,16,22,26,27,33,36,37,38,44,45$ and 54 . It is shows that some sub-basins on the western parts of study area that river has got westeast trending, are more active. But, some sub-basins on the eastern parts of study area that river has got northwest-southeast trending, are less active.

\section{Acknowledgements}

This work has funded by department of geology, Islamic Azad University, Science and Research branch, Tehran, Iran. Also, special thanks to vice-president for research in Science and Research branch, Tehran.

\section{References}

[1] Arian, M. (2013) Physiographic-Tectonic Zoning of Iran's Sedimentary Basins. Open Journal of Geology, 3, 169-177. https://doi.org/10.4236/ojg.2013.33020

[2] Qorashi, M. and Arian, M. (2011) Tectonics of Iran. Geologic Survey of Iran, Tehran, 336 p.

[3] Arian, M. (2011) Basement Tectonics and Geology of Iran. Asar Nafis Press, Qum, 300 p.

[4] Arian, M. (2011) A Preface on Salt Diapirism of Iran. Asar Nafis Press, Qum, 309 p.

[5] Arian, M. and Noroozpour, H. (2015) The Biggest Salt-Tongue Canopy of Central Iran. Open Journal of Geology, 5, 55-60. https://doi.org/10.4236/ojg.2015.52005

[6] Asadian, F., Pourkermani, M. and Arian, M. (2007) Tectonic Geomorphology of Salt Structures in the Garmsar-Lasjerd Area. Geographical Research, 39, 75-84.

[7] Pourkermani, M. and Arian, M. (1997) Salt Domes of Central Iran. Journal of Humanities, 
3, 29-41.

[8] Arian, M. (2012) Salt Diapirism and Tectonics. 2nd Edition, Asar Nafis Press, Qum, 319 p.

[9] Arian, M. and Noroozpour, H. (2015) Tectonic Geomorphology of Iran's Salt Structures. Open Journal of Geology, 5, 61-72. https://doi.org/10.4236/ojg.2015.52006

[10] Asadian, F. and Arian, M. (2009) Identification of Diapiric Provinces of Central Iran through Geological and Geographical Analysis. International Journal of Agriculture Environment \& Biotechnology, 2, 3443-3451.

[11] Arian, M. (2012) Clustering of Diapiric Provinces in the Central Iran Basin. Carbonates and Evaporites, 27, 9-18. https://doi.org/10.1007/s13146-011-0079-9

[12] Pourkermani, M. and Arian, M. (1998) Tectonic Geomorphology of Salt Domes in West of Zanjan Province, Iran. Geographical Research, 47, 44-53.

[13] Arian, M. and Feizi, F. (2010) The Significance of Faulting on the Surficial Spreading of Evaporitic Deposits in the Varamin-Semnan Area. Journal of Earth and Resources, 3, 1-20.

[14] Feizi, F., Arian, M. and Arian, A. (2015) Mud Diapirism on the Makran, Iran: Case Study on the Napag Mud Volcano. Open Journal of Geology, 5, 300-308. https://doi.org/10.4236/ojg.2015.55027

[15] Arian, M. and Sistanipour, A. (2015) Mud Diapirism on the Gorgan, North Iran. Open Journal of Geology, 5, 442-450.

[16] Arian, M. and Khodabakhshnezhad, A. (2015) Sedimentary Environments Can Be Changed by Geotechnology (Case Study: A Morphotectonic Idea for Design of Extensive Artificial Bay on the Iranian Plateau). International Journal of Geosciences, 6, 487-496. https://doi.org/10.4236/ijg.2015.65039

[17] Arian, M. (2011) Middle East Tectonics. AsarNafis Press, Qum, 236 p.

[18] Arian, M. (2010) Applied Seismotectonics. Farazamin Press, Tehran, 304 p.

[19] Arian, M. and Maleki, R. (2008) Neotectonics. Farazamin Research Center, Tehran, 150.

[20] Pourkermani, M. and Arian, M. (1998) Seismicity of Iran. Shahid Beheshti University Press, Tehran, 212.

[21] Pourkermani, M. and Arian, M. (1997) Seismotectonics. Dez Ab Consulting Engineers Company Press, Tehran, 270.

[22] Arian, M. and Aram, Z. (2014) Relative Tectonic Activity Classification in the Kermanshah Area, Western Iran. Solid Earth, 5, 1277-1291. https://doi.org/10.5194/se-5-1277-2014

[23] Mashal, M., PourKermani, M., Charchi, A., Almasian, M. and Arian, M. (2013) Pattern of Structural Geology Underground in Eastern of North Dezfol Embayment. Advances in Environmental Biology, 7, 260-268.

[24] Pazhoohan, M., Arian, M., Ghorashi, M. and Khosrotehrani, K. (2014) A Study of Drainage Pattern Responses to Active Tectonics in Tadvan Region, SW Iran. Geodynamics, 1, 36-41.

[25] Rahimi, N. and Arian, M. (2014) Tectonic Geomorphplogy of Kangavar-Sosangerd Region, West Iran. Advances in Environmental Biology, 8, 119-124.

[26] Arian, M. and Hashemi, A. (2008) Seismotectonic Zoning in the Zagros. Journal of Sciences, $18,63-76$.

[27] Arian, M., Ahmadnia, A., Qorashi, M. and Pourkermani, M. (2002) Structural Analysis of Mengharak Transcurrent Fault System in Zagros, Iran. Special Geo 2002 Conference Issue Geoarabia, 7, 209-210.

[28] Arian, M., Qorashi, M., Pourkermani, M. and Ahmadnia, A. (2003) Fractal Analysis of Mengharak Transcurrent Fault System in Zagros, Iran. 4th International Conference on Seismology and Earthquake Engineering, Tehran, 12-14 May 2003, 23.

[29] Baharvand, S., Pourkermani, M., Ajalloian, R., Arian, M. and Nouryazdan, A.R. (2010) 
Seymareh Landslide and Its Role in Environmental and Geomorphologic Changes of the Pole-Dokhtar Area. Journal of the Earth, 4, 13-24.

[30] Abdideh, M., Qorashi, M., Rangzan, K. and Arian, M. (2011) Assessment of Relative Active Tectonics Using Morphometric Analysis, Case Study of Dez River (Southwestern, Iran). Geosciences, 20, 33-46

[31] Arian, M., Qorashi, M., Pourkermani, M. and Ahmadnia, A. (2006) The Structural Significance Kareh Bas Transcurrent Fault System in the Zagros Fold and Thrust Belt. Geosciences, $15,126-133$.

[32] Arian, M. and Noroozpour, H. (2015) Seismic Activity and Fractal Geometry of Kareh Bas Fault System in Zagros, South of Iran. Open Journal of Geology, 5, 291-299. https://doi.org/10.4236/ojg.2015.55026

[33] Ehsani, J. and Arian, M. (2015) Quantitative Analysis of Relative Tectonic Activity in the Jarahi-Hendijan Basin Area, Zagros Iran. Geosciences Journal, 19, 1-15. https://doi.org/10.1007/s12303-015-0016-3

[34] Omidali, M., Arian, M. and Sorbi, A. (2015) Neotectonics of Boroujerd Area, SW Iran by Index of Active Tectonics. Open Journal of Geology, 5, 309-324. https://doi.org/10.4236/ojg.2015.55028

[35] Chegini, A., Sorbi, A. and Arian, M. (2015) Active Tectonics of Hamedan Area, West Iran. International Journal of Geography and Geology, 4, 109-128. https://doi.org/10.18488/journal.10/2015.4.6/10.6.109.128

[36] Maleki, Z., Arian, M., Solgi, A. and Ganjavian, M.A. (2014) The Elements of Fold Style Analysis in the Khaftar Anticline, Zagros, Iran. Open Journal of Geology, 4, 79-92. https://doi.org/10.4236/ojg.2014.43008

[37] Maleki, Z., Arian, M. and Solgi, A. (2014) Structural Style and Hydrocarbon Trap of Karbasi Anticline, in the Interior Fars Region, Zagros, Iran. Solid Earth Discussions, 6, 2143-2167. https://doi.org/10.5194/sed-6-2143-2014

[38] Ehsani, J., Arian, M. and Ghorashi, M. (2015) Geomorphic Signatures of Active Tectonics in the Jarahi-Hendijan Drainage Basin in the South West Iran. Geosciences, 24, 211-218.

[39] Khodabakhshnezhad, A., Pourkermani, M., Arian, M., Matkan, A.A. and Charchi, A. (2015) Active Tectonics of Great Karoun River Basin. Geosciences, 24, 13-28.

[40] Maleki, Z., Arian, M. and Solgi, A. and Ganjavian, M.A. (2015) Elements of Fold Style Analysis in the Karbasi Anticline, Interior Fars Region, Zagros. Geosciences, 24, 293-302.

[41] Baratpour, F. Arian, M. and Solgi, A. (2015) Geometric Analysis of Tukak and Kamarun Anticlines on Izeh Zone, Zagros. Geosciences, 24, 191-200.

[42] GholamhoseinFard, N., Sorbi, A. and Arian, M. (2015) Active Tectonics of Kangavar Area, West Iran. Open Journal of Geology, 5, 422-441. https://doi.org/10.4236/ojg.2015.56040

[43] Maleki, Z., Arian, M. and Solgi, A. (2015) Folding Pattern in the Fars Province, Zagros Folded Belt: Case Study on the Karbasi and Khaftar Anticlines, Interior Fars, Iran. Solid Earth Discussions, 7, 2347-2379. https://doi.org/10.5194/sed-7-2347-2015

[44] Alladin, Y., Talebian, M., Arian, M. and Ahmadi, M.M. (2015) Geotechnical Investigation and Seismic Zonation of Alluvial Deposits in Western Tehran. Geosciences, 24, 333-342.

[45] Taherkhani, B., Nazari, H., Pourkermani, M. and Arian, M. (2015) Geometry and Recent Kinematics of the North Qazvin Fault: Morphotectonic Approach. Geosciences, 24, 29-38.

[46] Haj Manuchehri, M., Arian, M., Ghorashi, M. and Solgi, A. (2015) Geomorphic Signatures of Active Tectonics in the Chalus Drainage Basin in the Alborz, Iran. Geosciences, 24, 273 280.

[47] Noroozpour, H., Arian, M. and Sorbi, A. (2015) Fault Movement Potentials in the TehranSemnan Region (North Iran). Open Journal of Geology, 5, 281-290. 
https://doi.org/10.4236/ojg.2015.55025

[48] Arian, M., Maleki, Z. and Noroozpour, H. (2011) Cenozoic Diastrophism and Deformational Events in the East Central Alborz. Journal of Basic and Applied Scientific Research, 1, 2394-2400.

[49] Feizi, F., Arian, A. and Rahmani, R. (2007) Seismotectonic Zoning in the Eastern Part of the Central Alborz. Journal of Sciences, 17, 151-164.

[50] Khavari, R., Arian, M. and Ghorashi, M. (2009) Neotectonics of the South Central Alborz Drainage Basin, in NW Tehran, N Iran. Journal of Applied Sciences, 9, 4115-4126. https://doi.org/10.3923/jas.2009.4115.4126

[51] Arian, M. and Bagha, N. (2012) Active Tectonics of Tehran Area, Iran. Journal of Basic and Applied Scientific Research, 2, 3805-3819.

[52] Bagha, N., Arian, M., Ghorashi, M., Pourkermani, M., El Hamdouni, R. and Solgi, A. (2014) Evaluation of Relative Tectonic Activity in the Tehran Basin, Central Alborz, Northern Iran. Geomorphology, 213, 66-87. https://doi.org/10.1016/j.geomorph.2013.12.041

[53] Arian, M. and Feizi, F. (2005) Application of Geomorphic Indices to the Assessment of Relative Tectonic Activity Levels in the Alborz-Central Iran Border Zone. Journal of Sciences, 15, 378-403.

[54] Arian, M., Bagha, N., Khavari, R. and Noroozpour, H. (2012) Seismic Sources and NeoTectonics of Tehran Area (North Iran). Indian Journal of Science and Technology, 5, 23792383.

[55] Moghimi, H., Arian, M. and Sorbi, A. (2015) Fault Movement Potential of Marzanabad Area, North Alborz, Iran. Open Journal of Geology, 5, 126-135.

https://doi.org/10.4236/ojg.2015.53012

[56] Arian, M. and Pourkermani, M. (2004) Tectonic Elements of South Flank in the East-Central Alborz Mountain. Journal of Sciences, 4, 359-368.

[57] Arian, M. and Qorashi, M. (2006) The Movement Potential Evaluation of the Major Quaternary Faults in Alborz-Central Iran Border Zone, from the East of Tehran to the East of Semnan. Journal of Geosciences, 15, 184-188.

[58] Poroohan, N., Pourkermani, M. and Arian, M. (2013) An Assessment of Relationship in F-Parameter and Paleostress Fields in Heterogeneous Lithologies: Roudbar Area (Northwest of Iran). Australian Journal of Basic \& Applied Sciences, 7, 933-942.

[59] Poroohan, N., Poukermani, M. and Arian, M. (2009) An Assessment on Correlations of Seismotectonic Parameters Preceding and Following Roudbar-Manjil Earthquake (Gilan, North of Iran). Australian Journal of Basic \& Applied Sciences, 3, 2643-2652.

[60] Farrokhnia, A.R., Pirasteh, S., Pourkermani, M. and Arian, M. (2011) Geo-Information Technology for Mass Wasting Hazard Zonation: Central-West Alborz-Iran. Disaster Advances, 4, 24-33.

[61] Khavari, R., Ghorashi, M. and Arian, M. (2009) Assessment of relative Active Tectonics, South Central Alborz (North Iran). EGU General Assembly Conference Abstracts, 11, 1137.

[62] Sorbi, A., Arian, M. and Pourkermani, M. (2009) The Movement Potential Evaluation of the Major Quaternary Faults in Tehran Quadrangle. Journal of the Earth, 19, 176-182.

[63] Feizi, F. and Arian, M. (2006) The Classification of Thrust Fronts in the Alborz-Central Iran Border Zone from the East of Varamin to the East of Semnan. Journal of Sciences, 16, 75-87.

[64] Arian, M. and Feizi, F. (2005) Application of Geomorphic Indices to the Assessment of Relative Tectonic Activity Levels in the Alborz-Central Iran Border Zone the Alborz-Central Iran Border Zone. Journal of Sciences, 15, 378-403.

[65] Arian, M. and Pourkermani, M. (2004) Structural Significance of North Semnan and Attary 
Faults in Alborz-Central Iran Border Zone. Journal of Sciences, 14, 4551-4569.

[66] Arian, M. and Pourkermani, M. (2005) Cenozoic Diastrophism and Deformational Events in the Southern Flank of Central-East Alborz. Journal of Faculty Earth Sciences, 10, 43-51.

[67] Arian, M., Pourkermani, M., Qorashi, M. and Ghasemi, M.R. (2003) North Semnan Fault System and Its Role on Basin Division. 8th Symposium of Geological Society of Iran, Shahrood University of Technology, Shahrood, 4-6 September 2003, 11-17.

[68] Pourkermani, M. and Arian, M. (2001) Structural Geomorphology of Northeastern Kurdistan. Journal of Humanities, 7, 37-48.

[69] Mardani, Z., Ghorashi, M. and Arian, M. (2011) Geomorphic Signatures of Active Tectonics in the Talaghanrud, Shahrud and Sefidrud Drainage Basins in Central Alborz, N Iran. Geosciences, 20, 159-166.

[70] Sorbi, A., Arian, M. and Pourkermani, M. (2011) The Application of Geomorphic Indices to the Assessment of Relative Tectonic Activity Levels in Tehran Quadrangle. Journal of the Earth, 6, 1-9.

[71] Khavari, R., Ghorashi, M., Arian, M. and Khosrotehrani, K. (2010) Geomorphic Signatures of Active Tectonics in the Karaj Drainage Basin in South Central Alborz, N Iran. Geosciences, 19, 67-74.

[72] Javadi Mousavi, E. and Arian, M. (2015) Tectonic Geomorphology of Atrak River, NE Iran. Open Journal of Geology, 5, 106-114. https://doi.org/10.4236/ojg.2015.53010

[73] Nouri, R., Jafari, M.R., Arian, M., Feizi, F. and Afzal, P. (2013) Correlation between Cu Mineralization and Major Faults Using Multifractal Modelling in the Tarom Area (NW Iran). Geologica Carpathica, 64, 409-416. https://doi.org/10.2478/geoca-2013-0028

[74] Nouri, R., Jafari, M.R., Arian, M., Feizi, F. and Afzal, P. (2013) Prospection for Copper Mineralization with Contribution of Remote Sensing, Geochemical and Mineralographical Data in Abhar 1: 100,000 Sheet, NW Iran. Archives of Mining Sciences, 58, 1071-1084. https://doi.org/10.2478/amsc-2013-0074

[75] Nouri, R., Afzal, P., Arian, M., Jafari, M. and Feizi, F. (2013) Reconnaissance of Copper and Gold Mineralization Using Analytical Hierarchy Process in the Rudbar 1: 100,000 Map Sheet, Northwest Iran. Journal of Mining and Metallurgy, 49, 9-19.

[76] Farrokhnia, A.R., Pirasteh, S., Pradhan, B., Pourkermani, M. and Arian, M. (2011) A Recent Scenario of Mass Wasting and Its Impact on the Transportation in Alborz Mountains, Iran Using Geo-Information Technology. Arabian Journal of Geosciences, 4, 1337-1349. https://doi.org/10.1007/s12517-010-0238-7

[77] Arian, M. and Nouri, R. (2015) Lineament Tectonics and Mineralization in Tarom Area, North Iran. Open Journal of Geology, 5, 115-124. https://doi.org/10.4236/ojg.2015.53011

[78] Feizi, F. and Arian, M. (2011) The Role of Structural Controllers in Geneses of Copper Deposits in 1: 50000 Map of Saiin Qaleh. Journal of Sciences, 21, 1-10.

[79] Arian, M., Qorashi, M. and Ahmadnia, A. (2003) Analysis of Behbahan Shear Zone. Iranian Journal of Geology, 1, 1-4.

[80] Bahiraee, S., Arian, M., Qorashi, M. and Solgi, M. (2015) The Movement Potential Evaluation of the Mosha Fault (The West of Firoozkuh to the Shahrestanak). Geosciences, 24, 123-126.

[81] Bagha, N., Ghorashi, M., Arian, M., Pourkermani, M. and Solgi, A. (2015) Neotectonic Analysis of Mosha-North Tehran Fault Zone, Based on Morphotectonic Features, Central Alborz, Northern Iran. Geosciences, 24, 41-52.

[82] Mosavi, E. and Arian, M. (2015) Neotectonics of KashafRud River, NE Iran by Modified Index of Active Tectonics (MIAT). International Journal of Geosciences, 6, 776-794. https://doi.org/10.4236/ijg.2015.67063 
[83] Nouri, R. and Arian, M. (2015) Structural Control on the Distribution of Hydrothermal Alteration Zones and Mineralization in Dastjerdeh Area Based on Remote Sensing Data, NW Iran. Bulletin of the Georgian National Academy of Sciences, 9, 79-86.

[84] Sistanipour, A. and Arian, M. (2015) Geometric Analysis of Davaran Fault System, Central Iran. Open Journal of Geology, 5, 458-469. https://doi.org/10.4236/ojg.2015.56043

[85] Nazemi, M., Ghorashi, M., Ghassemi, M.R. and Arian, M. (2015) Morphotectonics Features of Alluvial Fans Associated with Active Tectonics (Shotori Mountains, East of Tabas-Central Iran). Geosciences, 24, 91-100.

[86] Alizadeh, H. and Arian, M. (2015) Rule of Structural Factors in formation of Porphyry Copper Deposits in South western Part of Kerman Area, Iran. Open Journal of Geology, 5, 489-498. https://doi.org/10.4236/ojg.2015.57045

[87] Javadi Mosavi, E. and Arian, M. (2015) Neotectonics of Tabas Area, Central Iran by Index of Active Tectonics (IAT). Open Journal of Geology, 5, 209-223.

https://doi.org/10.4236/ojg.2015.54019

[88] Jamalian Daryani, N., Arian, M. and Rashidnezhad Omran, N. (2015) Tectonics and Mineralization of Copper in the Ardestan-Kahang Area, Central Iran by Remote Sensing. Open Journal of Geology, 5, 188-196. https://doi.org/10.4236/ojg.2015.54017

[89] Arian, M. and Pourkermani, M. (2001) Rivers Morphology and Active Tectonic (Reviewing the Current Status of Ghezel Ozon River in the Province of Zanjan). 5 th Conference of Geological Society of Iran, Tehran, 28-30 August 2001, 556.

[90] Eshghi, Z., Arian, M. and Pourkermani, M. (2012) Structural Investigation on the Lak Mining Area (Bueen Zahra) Based on Remote Sensing, Used for Its Mineralization. Journal of the Earth, 6, 145-155.

[91] Arian, M., Toudeshki, V.H. and Noroozpour, H. (2011) Active Tectonics of Qezel Ozan River Basin, NW Iran. Journal of Applied Environmental and Biological Sciences, 1, 291295.

[92] Alizadeh, H., Arian, M., Lotfi, M., Ghorashi, M. and Ghorbani, M. (2015) Determination of Porphyry Copper Deposit Locations Using Photo Lineament Factor in Northern Parts of the Dehaj-Sardoiyeh Belt. Geosciences, 24, 247-252.

[93] Housini Toudeshki, V., Pourkermani, M., Arian, M. and Khosrotehrani, K.H. (2011) Influence of Structures on the Ghezel Ozan River. Geosciences, 21, 55-60.

[94] Housini Toudeshki, V. and Arian, M. (2011) Morphotectonic Analysis in the Ghezel Ozan River Basin, NW Iran. Journal of Geography and Geology, 3, 258-260. https://doi.org/10.5539/jgg.v3n1p258

[95] Arian, M. (2015) Seismotectonic-Geologic Hazards Zoning of Iran. Earth Sciences Research Journal, 19, 7-13. https://doi.org/10.15446/esrj.v19n1.40664

[96] Arian, M., Pourkermani, M., Sistanipour, A. and Noroozpour, H. (2011) Kinematic Significance of Fold- and Fault-Related Fracture Systems in the Rafsanjan's Northeast Highlands (Central Iran). Journal of Basic and Applied Scientific Research, 1, 3398-3406.

[97] Arian, M., Pourkermani, M., Sistanipour, A. and Noroozpour, H. (2011) Seismicity and Fault Segmentation of Bafq-Baghin Fault System (Central Iran). Journal of Applied Environmental and Biological Sciences, 1, 382-396.

[98] Javadi Mosavi, E., Arian, M., Ghorashi, M. and Nazemi, M. (2012) Measurments of Geomorphic Indices in Tabas Area. Journal of the Earth, 7, 213-225.

[99] Arian, M. (2010) Earthquake-Fault Hazard Investigations in the Kerman Quadrangle. Journal of Sciences, 19, 176-182.

[100] Cox, R.T. (1994) Analysis of Drainage Basin Symmetry as a Rapid Technique to Identify Areas of Possible Quaternarytilt Block Tectonics: An Example from the Mississippi Em- 
bayment. Geological Society American Bulletin, 106, 571-581.

https://doi.org/10.1130/0016-7606(1994)106<0571:AODBSA >2.3.CO;2

[101] Salvany, J.M. (2004) Tilting Neotectonics of the Guadiamar Drainage Basin, SW Spain. Earth Surface Processes and Landforms, 29, 145-160. https://doi.org/10.1002/esp.1005

[102] Ezati, M. and Agh-Atabai, M. (2013) Active Tectonic Analysis of Atrak River Subbasin Located in NE Iran (East Alborz). Journal of Tethys, 1, 177-188.

Submit or recommend next manuscript to SCIRP and we will provide best service for you:

Accepting pre-submission inquiries through Email, Facebook, LinkedIn, Twitter, etc. A wide selection of journals (inclusive of 9 subjects, more than 200 journals)

Providing 24-hour high-quality service

User-friendly online submission system

Fair and swift peer-review system

Efficient typesetting and proofreading procedure

Display of the result of downloads and visits, as well as the number of cited articles

Maximum dissemination of your research work

Submit your manuscript at: http://papersubmission.scirp.org/

Or contact ojms@scirp.org 